\title{
SUSCEPTIBILITY OF FUNGI, MAINLY CHOCOLATE SPOT (Botrytis fabae SARD.), TO GAMMA IRRADIATION IN THE FABA BEAN CROP (Vicia faba L.)
}

\author{
Jesús M. E. Aguilar-Luna ${ }^{1}$, Salvador López-López ${ }^{1}$ y Juan M. Loeza-Corte ${ }^{2}$
}

\begin{abstract}
Fungi cause considerable losses in the faba bean crop in many regions of the world. The aim of the current research was to evaluate the susceptibility of faba bean to fungi, mainly chocolate spot, and its effect on yield, using seeds exposed to gamma irradiation. Faba bean seeds were cultivated in three regions: Hidalgo, Puebla and Tlaxcala, Mexico; the seeds were irradiated with a dose rate of $4.90 \mathrm{~Gy} \cdot \mathrm{min}^{-1}$ using a Gammacell 220 irradiator. The irradiation doses were 0, 20, 40, 60, 80, 160, 250 and $350 \mathrm{~Gy}$ of gamma rays with ${ }^{60} \mathrm{Co}$ radioisotopes. The irradiated seeds showed acceptable germination (75.70 \%) without visible damages, and survival was $53.62 \%$ until 118 days after sowing. When unirradiated seed was used, the susceptibility of the crop could reach $60 \%$ and the disease severity up to $34 \%$, with a disease progress rate of 0.006 units $^{-1 a y}{ }^{-1}$. The 40 Gy dose offered the best response to control the disease; up to $58.80 \mathrm{~g}$ of dry weight was obtained for every 100 seeds and a production of $4,442 \mathrm{~kg} \cdot \mathrm{ha}^{-1}$. In faba bean crop, up to $77 \%$ of the variation in yield was due to severity of fungi, mainly the chocolate spot. Additional keywords: Area under disease progress curve, mutagenesis, mutagenic effectiveness, radiosensitivity
\end{abstract}

\section{RESUMEN}

Susceptibilidad de los hongos, en especial, la mancha chocolate (Botrytis fabae Sard.) a la irradiación gamma en Vicia faba L. Las enfermedades fungosas causan considerables pérdidas en muchas regiones productores de haba en el mundo. El objetivo de la presente investigación fue evaluar la susceptibilidad del cultivo de haba a estas afectaciones, en especial, la mancha chocolate, $\mathrm{y}$ su efecto en el rendimiento, a partir del uso de semillas expuestas a irradiación gamma. Las semillas de haba se cultivaron en tres regiones de México: Hidalgo, Puebla y Tlaxcala, y fueron irradiadas con el Gammacell 220 a una tasa de 4,90 Gy· $\mathrm{min}^{-1}$. Las dosis de irradiación fueron: 0, 20, 40, 60, 80, 160, 250 y 350 Gy de rayos gamma con una fuente de radioisótopos ${ }^{60}$ Co. Las semillas irradiadas mostraron aceptable germinación (75,70 \%), sin daños visibles, con una supervivencia de 53,62 \% hasta los 118 días después de la siembra. Cuando se utilizó semilla sin irradiar, la susceptibilidad del cultivo alcanzó el 60 \% y la severidad de la enfermedad hasta $34 \%$, con una tasa de progreso de 0,006 unidad día ${ }^{-1}$. La dosis a 40 Gy es la que mejor respuesta ofreció para el control de la enfermedad, además de que se obtuvo hasta 58,80 g de peso seco por cada 100 semillas y una producción de $4442 \mathrm{~kg} \cdot \mathrm{ha}^{-1}$. En el cultivo de haba, hasta el 77 \% de la variación en el rendimiento se debió a la severidad del ataque de hongos, en especial, la mancha chocolate.

Palabras clave adicionales: Área bajo la curva de progreso, mutagénesis, efectividad mutagénica, radiosensibilidad

\section{INTRODUCTION}

The faba bean (Vicia faba L.) is an annual herbaceous plant (Fabaceae), cultivated in temperate climates. It has a high protein content besides carbohydrates, B vitamins, and minerals (Crépon et al., 2010). In Mexico, it is a seasonal crop with a planted area near 28,000 ha, and average yield of $1.23 \mathrm{Mg} \cdot \mathrm{ha}^{-1}$.
Among the diseases that affect the crop, the chocolate spot caused by the fungus Botrytis fabae Sard. is the most important in Mexico (Rojas et al., 2012) and other producing regions of the world (Etemadi et al., 2019). Globally, a reduction in bean production is observed because this crop is very susceptible to the disease (Terefe et al., 2015). It can cause a reduction in yield of 10 to $90 \%$ (Tivoli et al., 2006), since producers

Received: April 24, 2020

Accepted: December 5, 2020

${ }^{1}$ Benemerita Autonomous University of Puebla, Agroforest Engineering. Tetela de Ocampo, Puebla, México. e-mail: mao.aguilar@correo.buap.mx (corresponding author); salvador.lopez@alumno.buap.mx

${ }^{2}$ University of Cañada, Agroindustrial Engineering, Institute of Food Technology. Teotitlán de Flores Magón, Oaxaca, México. e-mail: manuel_loeza@unca.edu.mx 
generally use susceptible local varieties and do not apply fungicides or some other control method (Kora et al., 2017). The chocolate spot is a fungal disease, economically important because it damages the foliage and all green tissues, limiting the photosynthesis and causes losses by reducing the yield and quality of the affected seed (Kora et al., 2017).

The disease is activated in lengthy periods of high humidity and temperature, promoting the change from a non-aggressive phase (chocolate color in green tissues) to an aggressive phase (gray-brown color) (Terefe et al., 2015). Field recognition of the fungus in its non-aggressive and aggressive phases makes it possible to easily distinguish it since it is dominant over other fungi. The chocolate spot affects practically all faba bean producing regions in the world and has been reported by growers of haba production areas of Mexico in the last 30 years; therefore, efficient strategies for the integrated management of the disease should be sought, such as the development of resistant varieties (Bouhassan et al., 2004).

Mutagenesis is an important tool to increase variability in autogamous plants, without altering their original genetic composition (Ambavane et al., 2015). It can increase the genetic variability of certain characters, both useful and harmful (Ambavane et al., 2015); making selection and the probability of getting the desirable genotypes more effective, compared to conventional breeding methods (Raina et al., 2016).

Although there are several procedures used in mutagenesis, the use of gamma rays $\left({ }^{60} \mathrm{Co}\right)$ is one of the most used (Ulukapi and Ozmen, 2018). Gamma rays are less risky to human health than chemical mutagens (Khan and Tyagi, 2010); they are not toxic and do not require detoxification after use (Mba, 2013). Also, they have been used to develop tolerance to biotic-abiotic stress in plants grown from seed (Jain, 2010). Therefore, the objective of this work was to evaluate the susceptibility of the faba bean crop to fungal diseases, mainly chocolate spot and its effect on yield from the use of seeds exposed to gamma irradiation $\left({ }^{60} \mathrm{Co}\right)$.

\section{MATERIALS AND METHODS}

Faba bean seeds (with $12 \%$ humidity and 5 months of storage) were collected in the town of Tenzoncuahuictic, municipality of Ixtacamaxtitlan, Puebla, Mexico. We worked with the botanical 'Major' variety and the experiment was carried out in winter 2018, at three sites (Table 1). The seeds (approximately 600) were irradiated in the facilities of the National Institute for Nuclear Research, in Mexico with Gammacell 220 irradiator at a dose rate of $4.90 \mathrm{~Gy} \cdot \mathrm{min}^{-1}(1 \mathrm{~Gy}=1$ $\left.\mathrm{J} \cdot \mathrm{kg}^{-1}\right)$. The irradiation doses were $0,20,40,60$, $80,160,250$ and $350 \mathrm{~Gy}$ of gamma rays with a source of ${ }^{60} \mathrm{Co}$ radioisotopes.

Table 1. Experimental sites with faba bean production and incidence of fungi, mainly chocolate spot, in Mexico, winter 2018

\begin{tabular}{lccccc}
\hline Site, State & $\mathrm{N}$ & $\mathrm{W}$ & ALT $(\mathrm{m})$ & MAT $\left({ }^{\circ} \mathrm{C}\right)$ & MAP $(\mathrm{mm})$ \\
\hline Apan, Hidalgo (AH) & $19^{\circ} 41^{\prime} 09^{\prime \prime}$ & $9^{\circ} 24^{\prime} 45^{\prime \prime}$ & 2514 & 12.7 & 610 \\
Tetela de Ocampo, Puebla (TP) & $19^{\circ} 49^{\prime} 01^{\prime \prime}$ & $97^{\circ} 47^{\prime} 36^{\prime \prime}$ & 1764 & 13.9 & 971 \\
Españita, Tlaxcala (ET) & $19^{\circ} 27^{\prime} 41^{\prime \prime}$ & $9^{\circ} 25^{\prime} 23^{\prime \prime}$ & 2640 & 12.9 & 743 \\
\hline
\end{tabular}

N: north latitude. W: west longitude. ALT: altitude. MAT: mean annual temperature. MAP: mean annual precipitation

At each site, 24 furrows $(9 \mathrm{~m}$ each, $60 \mathrm{~cm}$ apart) were prepared, and one seed per hole was sown $30 \mathrm{~cm}$ between them, using three rows for each of the eight irradiation doses. The seeds were placed on both sides of the furrow, to promote the highest incidence of fungi in the plants. The management traditionally applied to the crop in each zone was followed.

The variables evaluated were the following:
Germination and survival. Observations of these variables were recorded from the seventh day after sowing, until harvest. For this purpose a total of 30 plants per treatment-site were selected randomly.

Mutagenic effectiveness and efficiency. Observations of these variables were recorded until the harvest in 30 random plants per treatment-site. Then, the following formulas, 
suggested by Ambavane et al. (2015), were used:

$$
\begin{gathered}
\text { Mutagenic effectiveness }=\frac{M}{\text { Doses of irradiation (Gy) }} \\
\text { Mutagenic efficiency }=\frac{M}{L}
\end{gathered}
$$

where $\mathrm{M}$ is the frequency expressed as percentage of chlorophyll mutation in $\mathrm{M}_{2}$ generation, estimated on $\mathrm{M}_{1}$ plant basis, $\mathrm{Gy}$ is a measure of the absorbed dose, and $\mathrm{L}$ is the percentage of lethality or reduction in survival.

Susceptibility and severity. Observations of these variables were recorded until harvest, in 30 plants randomly selected per treatment-site. For susceptibility, the scale proposed by Tivoli et al. (2006) was used and for severity (mean infection severity of the whole plant) the method of Hanouike and Hasanain (1986):

$$
\begin{gathered}
\text { Susceptibility }(\%)=\frac{\text { diseased plants }}{\text { total number of plants }}(100) \\
\text { Severity }(\%)=\frac{\sum(N x V)}{9 N}(100)
\end{gathered}
$$

Where $N$ is the number of infected leaves. $V$ is the numerical grade, and 9 is the higher degree in the category.

At all three sites, the prevalence of $B$. fabae was high and dominant over other fungi. It was easily recognized in its non-aggressive phase with chocolate color in green tissues, and gray- brown in its aggressive phase.

Area under disease progress curve (AUDPC). Disease severity values were recorded on 30 pretagged plants at weekly interval per treatment-site. They were calculated using the following formula, adapted by Jeger and Viljanen-Rollinson (2001):

$$
A U D P C=D\left[\frac{1}{2}\left(Y_{1}+Y_{k}\right)+\left(Y_{2}+Y_{3}+\ldots+Y_{k-1}\right)\right]
$$

where: $\mathrm{Y}_{1}, \mathrm{Y}_{2} \ldots \mathrm{Y}_{\mathrm{k}}$ are the $\mathrm{k}$ disease scores at a constant interval of $\mathrm{D}$ days.

Also, regression equations were developed to describe the disease progress rate (DPR) at the different irradiation doses.

Yield and its components. In 30 randomly selected plants per treatment-site, seed yield (SY) and hundred-seed weight (HSW) were quantified. The relative percent yield and yield losses by component were determined using the following formula:

$$
R Y L(\%)=\frac{\left(Y_{1}-Y_{2}\right)}{Y_{1}}(100)
$$

where RYL is the relative yield loss. $Y_{1}$ is the mean of the respective parameter in plants with irradiation. $Y_{2}$ is the mean of the respective parameter in plants without irradiation.

Also, a regression analysis between losses in seed yield and severity index of fungi was performed.

The experimental design was completely randomized with eight treatments and three repetitions. The data was subjected to one-way ANOVA, and the mean comparison tests were performed by the Tukey's $(P \leq 0.05)$ using Minitab Statistical Software v.18 (State College, PA, USA).

\section{RESULTS AND DISCUSSION}

Germination and survival. Faba bean germination started on day seven in TP and ended until day 16 in ET and $\mathrm{AH}$ (sites with drier conditions); the average value for Mexico, represented by these three sites was $75.70 \%$. In $\mathrm{TP}$, the percentages were higher regardless of the irradiation dose, as it was a rainier and warmer site ( $971 \mathrm{~mm}$ and $13.9{ }^{\circ} \mathrm{C}$, respectively). In Figure 1 , it is observed that the doses of 20 to 350 Gy had a significant effect $(P \leq 0.05)$ on the germination percentage; but from 20 to $60 \mathrm{~Gy}$ the germination remained constant with respect to the seeds without irradiation; with an average of $90.83 \%$. As the irradiation dose was increased from $80 \mathrm{~Gy}$, the germination percentage was reduced, up to $30.25 \%$, for the three sites. This indicates that doses lower than 60 Gy do not affect germination. In $\mathrm{AH}$, the conditions less favorable for germination were found with only $50 \%$ at 350 Gy, being up to $43 \%$ lower, compared to TP (from 0 to $60 \mathrm{~Gy}$ ). It is worth mentioning that, in non-irradiated seed, the percentages were high, from 89 to $93 \%$ and it remained constant at low doses of 20 to $60 \mathrm{~Gy}$. Up to 16 days after sowing (DAS), no visible symptoms of damage were observed in hypocotyl, cotyledon, epicotyl and nomophyles due to fungi attack in any site and irradiation dose.

The results showed that as the irradiation dose increased from $80 \mathrm{~Gy}$, the germination percentage decreased. Various studies show that germination is affected with the increase in the irradiation dose, like in Eleusine coracana (Ambavane et al., 2015), in Phaseolus vulgaris (Ulukapi and Ozmen, 2018) and Triticum monococcum since germination results from a combination of many 
cellular and metabolic events coordinated by a complex regulatory network of reactions (Well et al., 2018). In non-irradiated seeds, germination was $93 \%$. (Kiong et al., 2008) found that irradiation influenced germination since it caused delays in nutrient mobilization to the embryo, decreased respiratory rate and reduced the number of internal regulators.
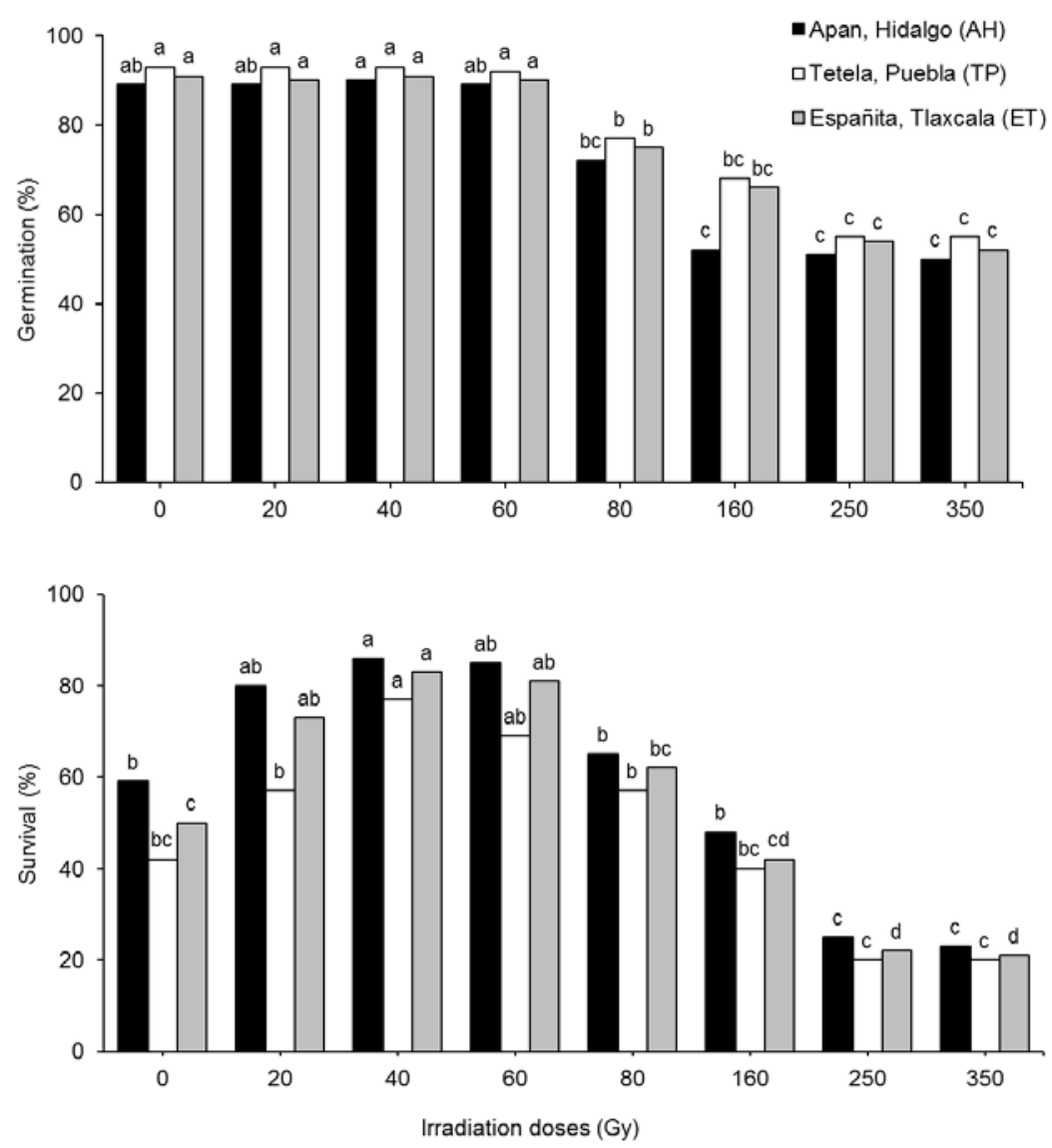

Figure 1. Germination and survival of faba beans from seeds irradiated with ${ }^{60} \mathrm{Co}$ (mutant $\mathrm{M}_{1}$ generation) in three sites of Mexico. Means with the same letter in a column are not significantly different according to Tukey test $(P \leq 0.05)$

Survival of faba bean plants varied $(P \leq 0.05)$ with the production environment and irradiation dose. Until harvest, the average value for Mexico represented by three sites (AH, TP and ET) was $53.62 \%$. At the site level, it was in AH where the highest percentages were obtained, independently of the irradiation dose, which contrasts with TP (a site with better germination conditions). In Figure 1 , it is observed that, for the three sites, the doses of 40 to $60 \mathrm{~Gy}$ are the ones that most influenced the survival of plants, which suggests that these doses give the plants a certain resistance to chocolate spot. The lowest value was in TP (20\%) at 250-350 Gy, while the highest was in $\mathrm{AH}$ (86 \%) at 40 Gy. When using seed without irradiating, the survival percentages were low, from 42 to $59 \%$, but they are even lower when the doses are increased above 160 and up to $350 \mathrm{~Gy}$. This suggests changes in the genotype and instability in the phenotypic expression, not necessarily due to the chocolate spot. If the seed is previously treated before sowing, with doses of 40 to $60 \mathrm{~Gy}$, there may be up to $29.83 \%$ more survival than when treatment with the mutagenic agent is not applied.

Like in germination, high doses of irradiation also contribute to the decrease in survival rate, although it could be increased up to $29.83 \%$ when low doses of 40 to $60 \mathrm{~Gy}$ were applied. In general, survival was low in the three producing sites of 
Mexico (AH, TP and ET) with an average of $53.62 \%$. Ulukapi and Ozmen (2018) concluded that low doses of irradiation stimulate the dry weight of the root and the aerial part of Phaseolus vulgaris, but a high doses affects survival. In Mexico, the site with the driest and coldest climate was $\mathrm{AH}$, and it was where the highest survival (>80 \%) was obtained. Kora et al. (2017) recommended that the sowing should be done when there is no high humidity or temperature, to reduce the aggressive phase of $B$. fabae and survival of the plants is not affected.

Mutagenic effectiveness and efficiency. The mutagenic effectiveness (index of the response of a crop to the increase doses of irradiation) and efficiency (proportion of mutations in relation to undesirable effects) were affected by the production environment (site) and the irradiation dose of the mutagenic agent (Table 2). But, regardless of the site, effectiveness and efficiency decreased as the irradiation dose increased up to 350 Gy, because 250 and 350 Gy doses produced many dead plants and plants with sterile pods, leading to a decrease in mutagenic efficiency. The average effectiveness for Mexico, represented by the three sites was 0.53 , and the average efficiency was 1.09. In general, the maximum effectiveness was recorded at $40 \mathrm{~Gy}$ with values from 0.791 to 0.814 and the maximum efficiency, also at $40 \mathrm{~Gy}$ with values from 1.21 to 1.29 . The highest effectiveness was obtained in $\mathrm{AH}$ at $40 \mathrm{~Gy}$ with 0.814 while the highest efficiency was also obtained in $\mathrm{AH}$ at $40 \mathrm{~Gy}$ with 1.29. Gamma irradiation can induce useful or harmful mutations in plants (Ambavane et al., 2015). Its effectiveness and efficiency generally decrease when the irradiation doses increase, as happened in the present study in faba bean plants at 250 and 350 Gy. Similar results were obtained in Glycine max (Khan and Tyagi, 2010), Lens culinaris (Wani, 2017) and Vigna radiata (Wani et al., 2017). Because in Mexico the effectiveness average and efficiency shown before were low, these values may have been affected by the environmental condition of the sites.

Table 2. Mutagenic effectiveness and efficiency in the $\mathrm{M}_{1}$ generation of faba bean irradiated with ${ }^{60} \mathrm{Co}$, cultivated in three sites of Mexico: AH (Apan, Hgo.), TP (Tetela, Pue.) and ET (Españita, Tlx.)

\begin{tabular}{ccccccc}
\hline $\begin{array}{c}\text { Doses } \\
(\mathrm{Gy})\end{array}$ & \multicolumn{3}{c}{ Mutagenic effectiveness } & \multicolumn{3}{c}{ Mutagenic efficiency } \\
\cline { 2 - 7 } & AH & TP & ET & AH & TP & ET \\
\hline 0 & --- & --- & --- & -- & -- \\
20 & 0.708 & 0.660 & 0.679 & 1.20 & 1.15 & 1.18 \\
40 & 0.814 & 0.791 & 0.802 & 1.29 & 1.21 & 1.25 \\
60 & 0.790 & 0.753 & 0.775 & 1.23 & 1.18 & 1.20 \\
80 & 0.665 & 0.629 & 0.654 & 1.05 & 1.04 & 1.04 \\
160 & 0.430 & 0.400 & 0.415 & 1.02 & 1.01 & 1.02 \\
250 & 0.237 & 0.208 & 0.223 & 1.00 & 1.00 & 1.00 \\
350 & 0.211 & 0.195 & 0.200 & 1.00 & 1.00 & 1.00 \\
\hline
\end{tabular}

Susceptibility and severity. The average susceptibility for Mexico, represented in three sites, was $27.97 \%$. However, it was in TP where higher values were obtained, attributed to the fact that in this region the average temperature (13.9 ${ }^{\circ} \mathrm{C}$ ) and precipitation (971 $\left.\mathrm{mm}\right)$ are higher, throughout the year, compared to ET and $\mathrm{AH}$. Irradiation doses of 40 to 350 Gy increased the plant susceptibility (Figure 2), although very low doses may not have an effect on disease control and very high doses seem to have damaged the embryo.

However, this percentage did not decrease as the dose increased to $350 \mathrm{~Gy}$, since in the three sites low doses (from 40 to 60 Gy) offered a better response to decrease the plant susceptibility to the fungus. At $20 \mathrm{~Gy}$, there was no change in the plants that favored the lowest percentage; the same happened in doses from 160 to $350 \mathrm{~Gy}$, where this percentage gradually increased. The site with the lowest percentage of susceptibility was AH with $10.60 \%$ at $40 \mathrm{~Gy}$, being 5.6 times lower, compared to the site with the highest values (TP at $0 \mathrm{~Gy}$ ) with $60.06 \%$.

Regardless of the site where the faba bean is grown, when the seed is not treated before sowing with gamma irradiation, the percentage of susceptibility is high, from 39.63 to $60.06 \%$ 
and always higher than at any other dose. The lesions caused by the chocolate spot in the faba bean crop, were more frequent and severe in the leaves than in other plant organ. The average severity for Mexico, represented by three sites was $17.65 \%$.
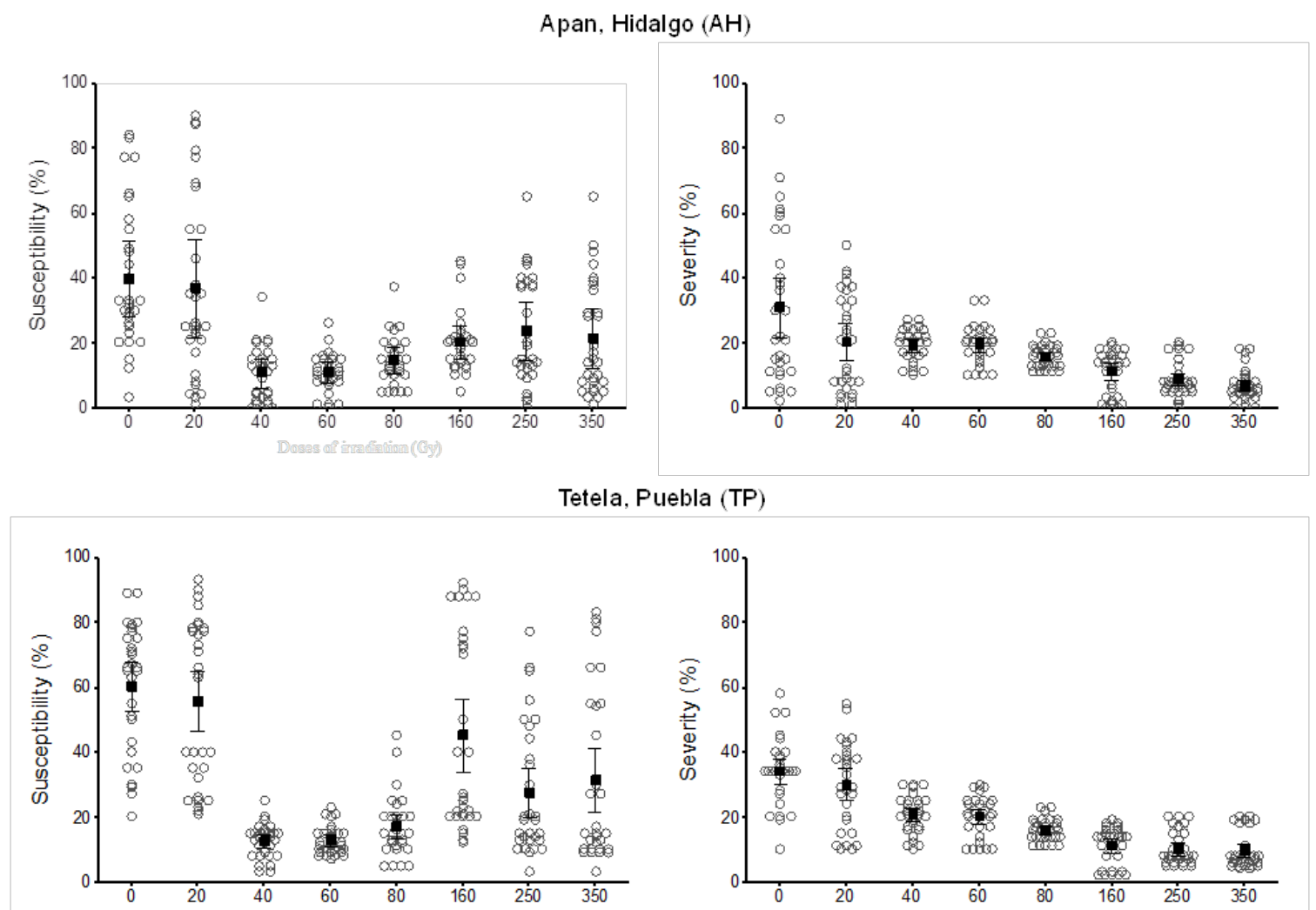

Españita, Tlaxcala (ET)
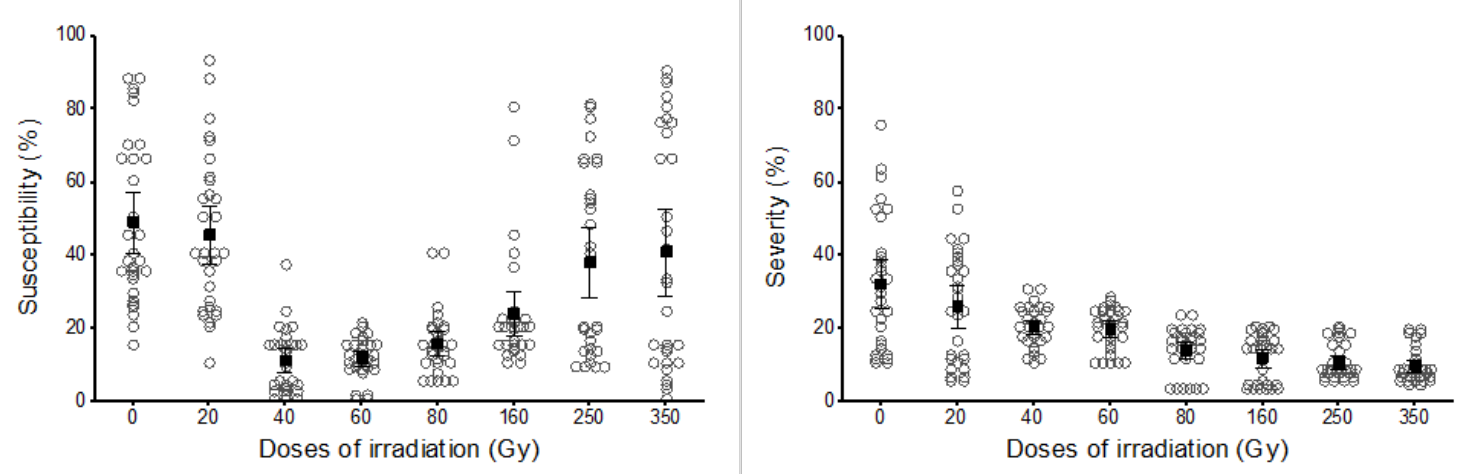

Figure 2. Susceptibility to fungi and disease severity in faba bean cultivation from irradiated seeds in three sites of Mexico. Black squares: the mean values. Vertical bars: the standard error

However, $\mathrm{AH}$ was the site with the lowest mean temperature $\left(12.7^{\circ} \mathrm{C}\right)$ and the lowest rainfall $(610 \mathrm{~mm})$, where the attack by fungi was less severe, with only $16.47 \%$. For the three sites, as the irradiation dose was higher (up to 350 Gy), the percentage of severity in the leaves was lower, with only $6.76 \%$. It is worth mentioning that when the seed for sowing is not irradiated, the severity of the disease can be high and varied from 30.76 to $34 \%$, but this value decreases up to five times if it is irradiated with $350 \mathrm{~Gy}$. This suggests that the irradiation doses of 20 to $350 \mathrm{~Gy}$ 
contribute in reducing the percentage of the disease severity (Figure 2).

In response to invasions by necrotrophic fungi, like $B$. fabae, plants develop different defense mechanisms, like lignification of the cell wall, production of phytoalexin, and acquisition of systemic resistance (Shetty et al., 2008). However, the effects of tissue age on the expression of defense-associated compounds have not been studied in detail since the production of defense compounds may assist necrotrophic pathogens to colonize healthy host tissues (El-Komy, 2015). The lesions of the chocolate spot were greater in lower leaves (older), than in the upper ones (younger) and the susceptibility did not decrease as the irradiation dose increased to $350 \mathrm{~Gy}$. There was a positive effect using doses of 40 to $60 \mathrm{~Gy}$ since the susceptibility decreased, compared to the control treatment ( $0 \mathrm{~Gy}$ ), which showed a value of $60.06 \%$. Villegas-Fernández et al. (2012) concluded that the resistance-susceptibility of $V$. faba against $B$. fabae appears to be more genotype specific than tissue age. The severity also decreased when the irradiation dose increased; the average value for the Mexican sites was $17.65 \%$, a much lower value than the $47.9 \%$ reported by Villegas-Fernández et al. (2012). In the same way, Sahile et al. (2010) found an incidence of the disease of 47 to $100 \%$ and a severity of 17 to $49 \%$, when precipitation and planting density were high, confirming that the susceptibility and severity of the chocolate spot varied between sites, due to altitude, temperature and precipitation.

Area under disease progress curve (AUDPC). The irradiation doses influenced the progress of the disease in the field, with statistical differences $(P \leq 0.05)$ in each site where $B$. fabae is present (Table 3). As the irradiation doses were higher the AUDPC decreased; the maximum AUDPC occurred in TP with $1842 \%$ in days, when no irradiation was applied. The use of gamma irradiation prevented the progress of the disease up to $68.7 \%$ at $350 \mathrm{~Gy}$, regardless of the site. In $\mathrm{AH}$, the average of the AUDPC was lower with $950.2 \%$ in days, compared to TP or ET. This represents a reduction of the disease progress of $21.7 \%$ in days in $\mathrm{AH}$ (less humid and colder) compared to TP (more humid and warmer site).

Table 3. Area under disease progress curve (AUDPC) for fungi, mainly chocolate spot, in three sites of Mexico: AH (Apan, Hgo.), TP (Tetela, Pue.) and ET (Españita, Tlx.) at different irradiation doses

\begin{tabular}{cccccccccc}
\hline & \multicolumn{10}{c}{ (\% days) } \\
\cline { 2 - 9 } Sites & $0 \mathrm{~Gy}$ & $20 \mathrm{~Gy}$ & $40 \mathrm{~Gy}$ & $60 \mathrm{~Gy}$ & $80 \mathrm{~Gy}$ & $160 \mathrm{~Gy}$ & $250 \mathrm{~Gy}$ & $350 \mathrm{~Gy}$ & Mean \\
\hline AH & $1417 \mathrm{a}$ & $1313 \mathrm{~b}$ & $1200 \mathrm{c}$ & $1054 \mathrm{~d}$ & $979 \mathrm{~d}$ & $582 \mathrm{e}$ & $571 \mathrm{e}$ & $486 \mathrm{e}$ & 950.2 \\
TP & $1842 \mathrm{a}$ & $1706 \mathrm{~b}$ & $1551 \mathrm{c}$ & $1382 \mathrm{~d}$ & $1218 \mathrm{e}$ & $773 \mathrm{f}$ & $688 \mathrm{f}$ & $550 \mathrm{~g}$ & 1213.7 \\
ET & $1650 \mathrm{a}$ & $1548 \mathrm{a}$ & $1400 \mathrm{~b}$ & $1278 \mathrm{c}$ & $1094 \mathrm{~d}$ & $669 \mathrm{e}$ & $635 \mathrm{e}$ & $500 \mathrm{f}$ & 1096.7 \\
\hline Mean & 1636.3 & 1522.3 & 1383.6 & 1238 & 1097 & 674.6 & 631.3 & 512 & \\
\hline
\end{tabular}

Means with the same letter in each file are not significantly different according to Tukey test $(P \leq 0.05)$

A regression equation based on the logistic model was used to describe the disease progress rate (DPR) of the chocolate spot in faba bean plants at different irradiation doses. The determination coefficient $\left(\mathrm{R}^{2}\right)$ varied from 75.40 to 83.68 in non-irradiated seeds, and from 29.66 to $55.45 \%$ in seeds irradiated with 350 Gy (highest dose), taking the severity a linear form, with decrements as the irradiation increased (Table 4). The analysis showed differences $(P \leq 0.05)$ from 20 Gy onwards.

In the AH, TP and ET sites, where unirradiated seeds were used, the chocolate spot increased at a rate of 0.033 to 0.037 units day $^{-1}$. This rate was exceeded approximately seven times due to the application of gamma irradiation at different doses (from 20 to $350 \mathrm{~Gy}$ ); the $350 \mathrm{~Gy}$ dose being the one that significantly reduced the DPR in the three sites. The highest DPR was in TP with an average of 0.006 units $\cdot$ day $^{-1}$. In this site, the highest AUDPC was recorded, reaching up to $1482 \%$ in days, at a dose of $0 \mathrm{~Gy}$, attributed to the fact that in this site, with humidity and temperature higher than in $\mathrm{AH}$ and ET, the conditions could have favored the onset of infection and a more accelerated DPR. 
Table 4. Disease progress rate (DPR) by fungi, mainly chocolate spot, in three sites of Mexico: AH (Apan, Hgo.), TP (Tetela, Pue.) and ET (Españita, Tlx.), at different irradiation doses

\begin{tabular}{|c|c|c|c|c|}
\hline Sites & $\begin{array}{l}\text { Doses } \\
\text { (Gy) }\end{array}$ & $\begin{array}{c}\text { DPR } \\
\text { (units·day }{ }^{-1} \text { ) }\end{array}$ & $\begin{array}{l}\mathrm{R}^{2} \\
(\%)^{\mathrm{b}}\end{array}$ & $\begin{array}{c}\text { Significance } \\
(P)\end{array}$ \\
\hline \multirow[t]{9}{*}{$\mathrm{AH}$} & 0 & 0.033 & 77.12 & 0.05 \\
\hline & 20 & 0.002 & 55.40 & 0.02 \\
\hline & 40 & 0.003 & 70.27 & 0.00 \\
\hline & 60 & 0.004 & 68.52 & 0.00 \\
\hline & 80 & 0.005 & 62.91 & 0.03 \\
\hline & 160 & 0.008 & 63.93 & 0.02 \\
\hline & 250 & -0.005 & 54.78 & 0.00 \\
\hline & 350 & -0.006 & 55.45 & 0.03 \\
\hline & Mean & 0.005 & 63.54 & \\
\hline \multirow[t]{9}{*}{$\mathrm{TP}$} & 0 & 0.037 & 75.40 & 0.04 \\
\hline & 20 & 0.003 & 50.08 & 0.05 \\
\hline & 40 & 0.004 & 48.71 & 0.03 \\
\hline & 60 & 0.005 & 47.93 & 0.00 \\
\hline & 80 & 0.006 & 53.12 & 0.01 \\
\hline & 160 & 0.009 & 43.74 & 0.01 \\
\hline & 250 & -0.007 & 28.94 & 0.02 \\
\hline & 350 & -0.008 & 29.66 & 0.05 \\
\hline & Mean & 0.006 & 47.19 & \\
\hline \multirow[t]{9}{*}{ ET } & 0 & 0.034 & 83.68 & 0.02 \\
\hline & 20 & 0.002 & 58.95 & 0.05 \\
\hline & 40 & 0.003 & 47.87 & 0.03 \\
\hline & 60 & 0.004 & 50.16 & 0.00 \\
\hline & 80 & 0.005 & 65.98 & 0.04 \\
\hline & 160 & 0.008 & 66.87 & 0.02 \\
\hline & 250 & -0.006 & 27.91 & 0.04 \\
\hline & 350 & -0.007 & 37.60 & 0.05 \\
\hline & Mean & 0.005 & 54.87 & \\
\hline
\end{tabular}

aStandar error of main factor. ${ }^{b}$ Coefficient of determination or proportion explained by the model

Kora et al. (2017) found similar results with $1282 \%$ in days, in Ethiopia, and Terefe et al. (2015) concluded that the chocolate spot can reach epidemic levels in a few days. Therefore, irradiation of the seeds before sowing helps to decrease AUDPC when the doses increased. However, low AUDPC values were not necessarily related to a higher yield, since at 350 Gy the SY was only $240 \mathrm{~kg} \cdot \mathrm{ha}^{-1}$ (Table 5) and the highest yields were obtained with 40 Gy. This finding contrasts with the values obtained by ElSayed et al. (2011) in five faba bean cultivars. Irradiation at $40 \mathrm{~Gy}$ increased the yield and decreased DPR, while in the non-irradiated seeds the DPR increased from 0.033 to 0.037 units $\cdot$ day $^{-1}$, that is, seven times higher.

As in the other variables, AUDPC and DPR are favored by conditions of low relative humidity and low temperature (El-Komy et al., 2015; Haile et al., 2016).

Yield and its components. The interaction between irradiation dose and sites showed statistical differences $(P \leq 0.05)$ in yield of faba bean (Table 5). In AH, the highest SY was 4,442 $\mathrm{kg} \cdot \mathrm{ha}^{-1}$ obtained with $40 \mathrm{~Gy}$. At the site level, the highest SY occurred in $\mathrm{AH}$ with an average of $2,508.87 \mathrm{~kg} \cdot \mathrm{ha}^{-1}$. The lowest relative yield loses (RYL) of SY were obtained with 40 Gy (no losses) in the three sites, while the highest RYL of SY was found at a dose of $350 \mathrm{~Gy}$ in TP. 
Important increases of RYL were recorded with doses below $40 \mathrm{~Gy}$ and above $60 \mathrm{~Gy}$ in the three sites. The doses of 40 to $60 \mathrm{~Gy}$ were the ones that offered the best response to the RYL of SY.

Table 5. Yield components of faba bean and losses due to fungi, mainly chocolate spot in three sites of Mexico: AH (Apan, Hgo.), TP (Tetela, Pue.) and ET (Españita, Tlx.), at different irradiation doses

\begin{tabular}{|c|c|c|c|c|c|}
\hline Sites & Doses (Gy) & $\mathrm{SY}\left(\mathrm{kg} \cdot \mathrm{ha}^{-1}\right)$ & RYL (\%) & HSW (g) & RYL (\%) \\
\hline \multirow[t]{10}{*}{$\mathrm{AH}$} & 0 & 1280 de & 31.94 & $46.68 \mathrm{~cd}$ & 12.30 \\
\hline & 20 & $3881 \mathrm{~b}$ & 12.28 & $50.71 \mathrm{ab}$ & 2.50 \\
\hline & 40 & 4442 a & 0.00 & 58.80 a & 0.00 \\
\hline & 60 & $4009 \mathrm{~b}$ & 4.55 & $53.91 \mathrm{a}$ & 1.34 \\
\hline & 80 & 3550 bc & 24.36 & 47.82 bc & 2.93 \\
\hline & 160 & $2396 \mathrm{~cd}$ & 36.11 & $43.90 \mathrm{~cd}$ & 13.05 \\
\hline & 250 & $273 \mathrm{f}$ & 54.73 & $40.82 \mathrm{e}$ & 18.39 \\
\hline & 350 & $240 \mathrm{f}$ & 59.41 & $40.71 \mathrm{e}$ & 18.44 \\
\hline & Mean & 2508.87 & & 47.91 & \\
\hline & CV (\%) & 11.86 & & 5.35 & \\
\hline \multirow[t]{10}{*}{$\mathrm{TP}$} & 0 & 1055 de & 35.84 & $44.57 \mathrm{~cd}$ & 14.61 \\
\hline & 20 & 3122 c & 19.13 & 47.83 bc & 2.71 \\
\hline & 40 & 3527 bc & 0.00 & $54.52 \mathrm{a}$ & 0.00 \\
\hline & 60 & 3495 bc & 7.96 & $49.99 \mathrm{ab}$ & 1.84 \\
\hline & 80 & $2400 \mathrm{~cd}$ & 26.39 & $45.44 \mathrm{~cd}$ & 3.50 \\
\hline & 160 & 1301 de & 39.14 & $42.55 \mathrm{de}$ & 13.93 \\
\hline & 250 & $264 \mathrm{f}$ & 56.01 & 40.18 e & 18.80 \\
\hline & 350 & $243 \mathrm{f}$ & 61.63 & $40.21 \mathrm{e}$ & 18.81 \\
\hline & Mean & 1925.87 & & 45.66 & \\
\hline & CV (\%) & 19.27 & & 3.71 & \\
\hline \multirow[t]{10}{*}{ ET } & 0 & 1263 de & 33.78 & $45.66 \mathrm{~cd}$ & 12.87 \\
\hline & 20 & 3517 bc & 15.82 & 48.32 bc & 2.58 \\
\hline & 40 & $4082 \mathrm{~b}$ & 0.00 & $54.05 \mathrm{a}$ & 0.00 \\
\hline & 60 & $4000 \mathrm{~b}$ & 7.77 & $51.08 \mathrm{ab}$ & 1.70 \\
\hline & 80 & 3384 c & 25.58 & 47.55 bc & 3.50 \\
\hline & 160 & $2020 \mathrm{~cd}$ & 36.85 & 42.16 de & 13.52 \\
\hline & 250 & $269 \mathrm{f}$ & 54.83 & 41.03 de & 18.78 \\
\hline & 350 & $256 \mathrm{f}$ & 61.22 & 41.00 de & 19.00 \\
\hline & Mean & 2348.87 & & 46.35 & \\
\hline & CV (\%) & 12.60 & & 5.94 & \\
\hline CV (\%) & & 14.57 & & 5.00 & \\
\hline
\end{tabular}

SY: seed yield. RYL: relative loss. HSW: hundred seed weight. Means with the same letter in a column are not significantly different according to Tukey test $(P \leq 0.05)$. CV: coefficient of variation

The effect of irradiation doses was also seen in HSW in the three sites (Table 5). At the site level, the highest mean was $47.91 \mathrm{~g}$, obtained in $\mathrm{AH}$, which was the least susceptible site for the disease progression. The highest HSW was $58.80 \mathrm{~g}$, obtained in AH, with a dose of $40 \mathrm{~Gy}$. The lowest was $40.18 \mathrm{~g}$, obtained in TP with $250 \mathrm{~Gy}$. The highest RYL of HSW were from 250 to 350 Gy (high doses), with 18.39 to $19.00 \%$, while from 40 to 60 Gy (low doses) the losses were minimal (0 to $1.84 \%$ ) in any site.
The average yield obtained in this investigation $\left(2508.87 \mathrm{~kg} \cdot \mathrm{ha}^{-1}\right)$ are lower than that reported by Kora et al. (2017), within the range of those obtained by Etemadi et al. (2018), and higher than the average yield of small producers (CSA, 2014), as well as the yield of improved cultivars in Ethiopia (Sahile et al., 2010). Yield variations may be attributed to genetic variability, seed size, planting density, seed purpose (fresh or dry consumption) and chocolate spot incidence (Etemadi et al., 2019). 
The relationship between yield components is compensatory and mutually interdependent; because a significant change in a yield component does not necessarily affect the final yield in SY. However, it is possible to obtain a higher SY and HSW when all yield components are maximized (Mirshekari et al., 2013). The linear regression of the severity index due to fungi in the yield of faba bean and its components, revealed statistical differences between sites and irradiation doses (Figure 3). In $\mathrm{AH}$, the slope of the regression line was (-75.381) indicates that for each unit increase in the percentage severity index, there was a loss of SY of $75.381 \mathrm{~kg} \cdot \mathrm{ha}^{-1}$ at $118 \mathrm{DAS}$. And based on the coefficient of determination $\left(\mathrm{R}^{2}\right)$, the equation explains that approximately $77 \%$ of the variation in yield was due to the severity of the disease. Similar considerations can be made for the other two sites, and confirm that the plant yield is highly influenced by the severity of the disease and indicates that the linear regression of the percentage of severity can be used to predict the loss of yield in faba beans with a high coefficient of determination.
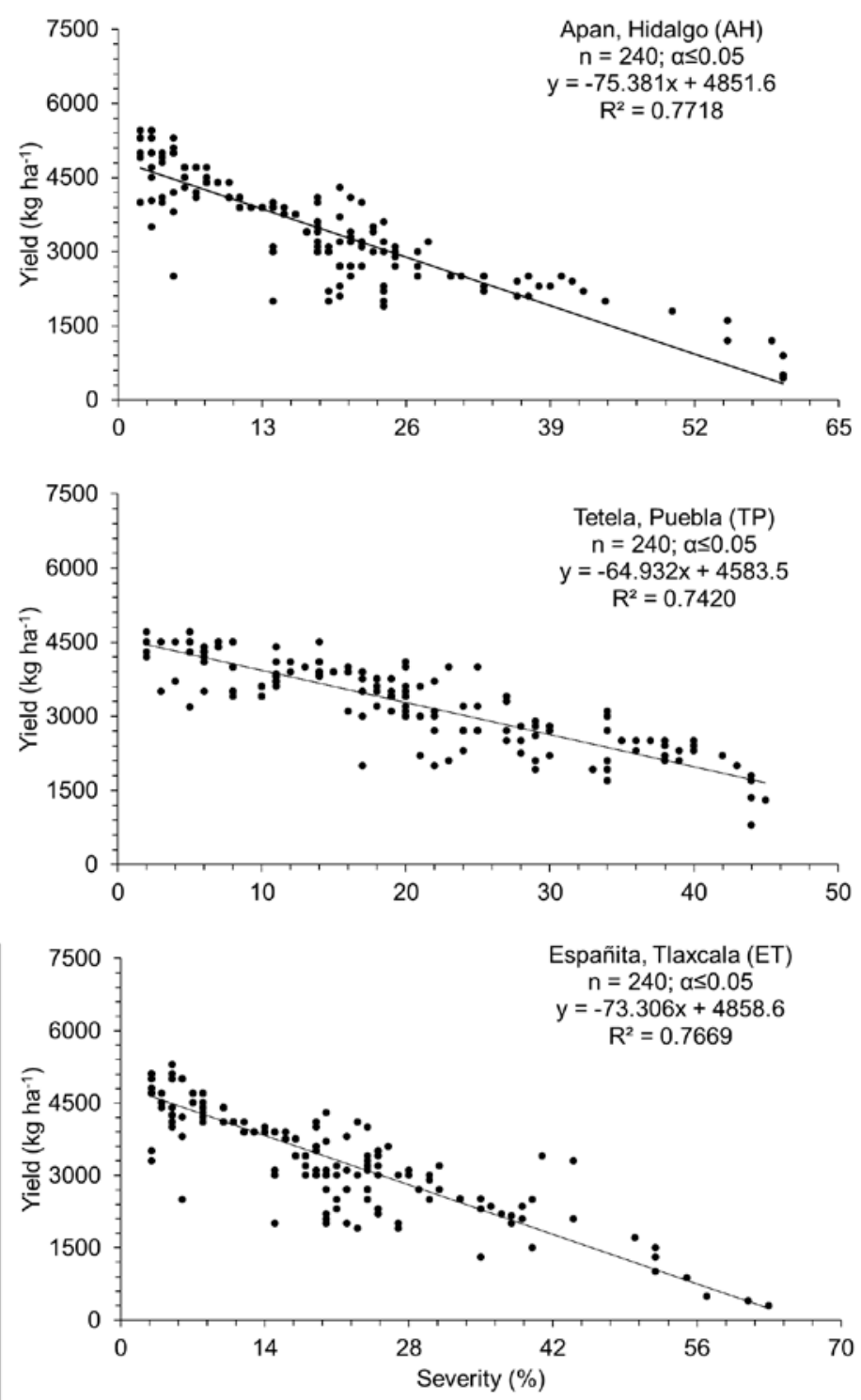

Figure 3. Relationship between losses in faba bean seed yield and severity index of fungi, mainly chocolate spot, at 118 DAS in three sites of Mexico 
According to the averages of the regression coefficients of the lines and their corresponding $\mathrm{R}^{2}$ shown in Figure 3, it was obtained that up to 118 DAS, the RYL of SY average in the Mexican studied sites were $71.20 \mathrm{~kg} \cdot \mathrm{ha}^{-1}$ due to the presence of the disease, and of these RYL, $76.02 \%$ was attributed to the severity of the disease. This result confirms that of Sahile et al. (2010) who concluded that the severity of the disease is negatively related to yield and its components.

\section{CONCLUSIONS}

The irradiation doses of 20 to $350 \mathrm{~Gy}$ of gamma rays to seeds influenced germination, survival, susceptibility and crop yield and they reduce the severity and progress of the diseases, mainly the chocolate spot. A low dosage of $40 \mathrm{~Gy}$ offered the best response for the control of the disease since high doses of 250 and $350 \mathrm{~Gy}$, reduced germination, survival and produce many sterile pods, leading to a decrease in mutagenic effectiveness and efficiency. It was determined that the coldest and least humid producing regions are related to a lower susceptibility and severity of fungal diseases as well as with a higher faba bean yield.

\section{LITERATURE CITED}

1. Ambavane, A.R., S.V. Sawardekar, S.A. Sawantdesai and N.B. Gokhale. 2015. Studies on mutagenic effectiveness and efficiency of gamma rays and its effect on quantitative traits in finger millet (Eleusine coracana L. Gaertn). Journal of Radiation Research and Applied Sciences 8(1): 120-125.

2. Bouhassan, A., M. Sadiki and B. Tivoli. 2004. Evaluation of a collection of faba bean (Vicia faba L.) genotypes originating from the Maghreb for resistance to chocolate spot (Botrytis fabae) by assessment in the field and laboratory. Euphytica 135: 55-62.

3. Crépon, K., P. Marget, C. Peyronnet, B. Carrouee, P. Arese and G. Duc. 2010. Nutritional value of faba bean (Vicia faba L.) seeds for feed and food. Field Crops Research 115(3): 329-339.

4. CSA (Central Statistical Agency). 2014.
Report on area and production of major crops (private peasant holdings, meher season). Statistical Bulletin 1: 10-14.

5. El-Komy, M.H., A.A. Saleh and Y.Y. Molan. 2015. Resistance/susceptibility of faba bean to Botrytis fabae: the causal agent of chocolate spot with respect to leaf position. International Journal of Agriculture and Biology 17(4): 691701.

6. El-Sayed, A. Sahar, R.Z. El-Shennawy and A.I. Ismail. 2011. Fungicidal management of chocolate spot of faba bean and assessment of yield losses due to the disease. Annals of Agricultural Science 56(1): 27-35.

7. Etemadi, F., M. Hashemi, O. Zandvakili and F.X. Mangan. 2018. Phenology, yield and growth pattern of faba bean varieties. International Journal of Plant Production 12: 243-250.

8. Etemadi, F., M. Hashemi, A.V. Barker, O.R. Zandvakili and X. Liu. 2019. Agronomy, nutritional value, and medicinal application of faba bean (Vicia faba L.). Horticultural Plant Journal 5(4): 170-182.

9. Haile, M., G. Adugna and F. Lemessa. 2016. Reactions of improved faba bean varieties to chocolate spot (Botrytis fabae Sard.) epidemics across contrasting altitudes in southwest Ethiopia. African Journal of Agricultural Research 11(10): 837-848.

10.Hanouike, S.B. and M.A. Hasanain. 1986. Inhibition of Botrytis fabae in the philosopher of Vicia faba leaves. FABIS Newsletter 16: 4144.

11.Jain, S.M. 2010. Mutagenesis in crop improvement under the climate change. Romanian Biotechnological Letters 15(2): 88106.

12.Jeger, M. and S. Viljanen-Rollinson. 2001. The use of the area under the disease-progress curve (AUDPC) to assess quantitative disease resistance in crop cultivars. Theoretical and Applied Genetics 102: 32-40.

13.Khan, M.H. and S.D. Tyagi. 2010. Studies on effectiveness and efficiency of gamma rays, EMS and their combination in soybean [Glycine max (L.) Merrill.]. Journal of Plant Breeding and Crop Science 2: 55-58.

14.Kiong, A.L.P., A.G. Lai, S. Hussein and A.R. 
Harun. 2008. Physiological responses of Orthosiphon stamineus plantlets to gamma irradiation. American-Eurasian Journal of Sustainable Agriculture 2(2): 135-149.

15.Kora, D., T. Hussein and S. Ahmed. 2017. Management of chocolate spot (Botrytis fabae L.) on faba bean in Bale Highland's, Ethiopia. Journal of Plant Sciences 5(4): 120-129.

16. Mba, C. 2013. Induced mutations unleash the potentials of plant genetic resources for food and agriculture. Agronomy 3(1): 200-231.

17.Mirshekari, M., N. Majnounhosseini, R. Amiri, A. Moslehi and O.R. Zandvakili. 2013. Effects of sowing date and irrigation treatment on safflower seed quality. Journal of Agricultural Science and Technology 15(3): 505-515.

18.Raina, A., R.A. Laskar, S. Khursheed, R. Amin, Y.R. Tantray, K. Parveen and S. Khan. 2016. Role of mutation breeding in crop improvement - past, present and future. Asian Research Journal of Agriculture 2(2): 1-13.

19.Rojas-Tiempo, J., R. Díaz-Ruíz, F. ÁlvarezGaxiola, J. Ocampo-Mendoza and A. Escalante-Estrada. 2012. Tecnología de producción de haba y características socioeconómicas de productores en Puebla y Tlaxcala. Revista Mexicana de Ciencias Agrícolas 3(1): 35-49.

20.Sahile, S., C. Fininsa, P.K. Sakhuja and S. Ahmed. 2010. Yield loss of faba bean (Vicia faba) due to chocolate spot (Botrytis fabae) in sole and mixed cropping systems in Ethiopia. Archives of Phytopathology and Plant Protection 43(12): 1144-1159.

21.Shetty, N.P., H.J.L. Jørgensen, J.D. Jensen, D.B. Collinge and S. Shetty. 2008. Roles of reactive oxygen species in interactions between plants and pathogens. European Journal of Plant Pathology 121: 267-280.

22.Terefe, H., C. Fininsa, S. Sahile, M. Dejene and K. Tesfaye. 2015. Effect of integrated cultural practices on the epidemics of chocolate spot (Botrytis fabae) of faba bean (Vicia faba L.) in Hararghe Highlands, Ethiopia. Global Journal of Pests, Diseases and Crop Protection 3(4): 113-123.

23.Tivoli, B., A. Baranger, C.M. Avila, S. Banniza, M. Barbetti, W. Chen et al. 2006. Screening techniques and sources of resistance to foliar diseases caused by major necrotrophic fungi in grain legumes. Euphytica 147(1): 223253.

24.Ulukapi, K. and S.F. Ozmen. 2018. Study of the effect of irradiation $\left({ }^{60} \mathrm{Co}\right)$ on $\mathrm{M}_{1}$ plants of common bean (Phaseolus vulgaris L.) cultivars and determined of proper doses for mutation breeding. Journal of Radiation Research and Applied Sciences 11(2): 157-161.

25.Villegas-Fernández, A.M., J.C. Sillero and D. Rubiales. 2012. Screening faba bean for chocolate spot resistance, evaluation methods and effects of age of host tissue and temperature. European Journal of Plant Pathology 132: 443-453.

26.Wani, M.R. 2017. Induced chlorophyll mutations, comparative mutagenic effectiveness and efficiency of chemical mutagens in lentils (Lens culinaris Medik). Asian Journal of Plant Sciences 16(4): 221226.

27.Wani, M.R., A.R. Dar, A. Tak, I. Amin, N.H. Shah, R. Rehman, M.Y. Baba, A. Raina, R. Laskar, M.I. Kozgar and S. Khan. 2017. Chemo-induced pod and seed mutants in mungbean (Vigna radiata L. Wilczek). SAARC Journal of Agriculture 15(2): 57-67.

28.Well, E.V., A. Fossey and M. Booyse. 2018. Efficiency of energy conversion and growth of gamma irradiated embryos and young seedlings of Triticum monococcum L. cultivar Einkorn. Journal of Radiation Research and Applied Sciences 11(1): 75-82. 